\title{
МІЖНАРОДНО-ПРАВОВІ ГАРАНТІЇ ПРАВА НА КОМПРОМІС У КРИМІНАЛЬНОМУ СУДОЧИНСТВІ
}

\author{
СІРОТКІНА Марія Вячеславівна - кандидат юридичних наук, здобувач \\ кафедри кримінального процесу та криміналістики Інституту права Київського \\ національного університету імені Тараса Шевченка
}

УДК $343.131(477)$

DOI 10.32782/LAW.2020.3.22

\begin{abstract}
Вступ
Незважаючи на суттєві переваги процедур відновного правосуддя, неформальний характер під час їх застосування містить у собі небезпеку порушення прав сторін конфлікту. У зв'язку з цим, як зазначає у своїх рішеннях Европейський суд з прав людини, будь-яка відмова від процесуальних прав повинна завжди бути зроблена у недвозначній формі і супроводжуватися мінімальними гарантіями, співмірними з їі важливістю. Крім того, вона не повинна суперечити жодному
\end{abstract} важливому суспільному інтересу [1].

У юридичній літературі питанням, пов'язаним з гарантуванням прав учасників кримінального процесу під час альтернативних судовому способів вирішення кримінально-правового конфлікту, присвятили праці Р.В. Новак, Г.Ю. Саєнко, А.С. Трекке, П.В. Холодило та ін.

У своїх дисертаційних дослідженнях автори неодноразово звертали увагу на необхідність гарантування прав підозрюваного (обвинуваченого), потерпілого, юридичної особи нормами чинного кримінального процесуального законодавства [2, с. 1; 3, с. 15].

Однак, ефективна реалізація права на компроміс відповідно до положень національного законодавства була б неможливою без впровадження міжнародних стандартів у правову систему України.

\section{Постановка завдання}

Враховуючи зазначене, метою статті є аналіз кримінально-процесуальних гаран- тій реалізації особою права на компроміс, закріплених у міжнародно-правових актах обов'язкового та рекомендаційного характеру.

\section{Результати дослідження}

Під гарантіями у кримінально-процесуальній науці розуміють систему правових засобів, встановлених законом для належного відправлення правосуддя, захисту прав і свобод людини в кримінальному процесі, здійснення завдань судочинства у кримінальних справах $[4$, с. $75 ; 5$, с. 229230].

На думку А.С. Стройкової кримінально-процесуальні гарантії - це встановлені кримінально-процесуальним законом правові засоби, якими охороняються і захищаються права і законні інтереси осіб, які беруть участь у кримінальному процесі, що включають як відповідні процесуальні приписи, так і діяльність відповідних державних органів, посадових та інших осіб за їх реалізації [6, с. 38]. Автор включив в поняття такі значимі ознаки, як «охорона і захист законних інтересів» і «діяльність державних органів і посадових осіб щодо реалізації їх охорони і захисту цих інтересів».

Найбільш повне, на нашу думку, визначення цього поняття наводить Ю.А. Іванов. Він розглядає кримінально-процесуальні гарантії як систему правових засобів забезпечення успішного вирішення завдань правосуддя і охорони законних інтересів 


\section{Кримінальне право, кримінальний процес та криміналістика}

усіх учасників провадження, що передбачає суворе дотримання встановлених законом форм і принципів судочинства, закріплення прав учасників процесу і умов їх реалізації, точне виконання обов'язків посадовими особами та органами, що здійснюють кримінально-процесуальну діяльність [7, с. 215].

3 огляду на це, кримінально-процесуальні гарантії - перш за все правові засоби. У розділі III Додатку до Резолюції 2002/12 Економічної і Соціальної Ради від 24 липня 2002 р. «Основні принципи застосування програм реституційного правосуддя в питаннях кримінального правосуддя» визначено, що держави повинні встановлювати керівні принципи i стандарти, які регулюють застосування програм реституційного правосуддя. Такі керівні принципи і стандарти повинні забезпечувати дотримання основних положень, що містяться в цьому документі, i стосуватися, зокрема, наступного:

а) умов для передачі справ програмами реституційного правосуддя;

b) розгляду справ після реституційного процесу;

с) кваліфікації, підготовки і оцінки посередників;

d) управління програмами реституційного правосуддя;

е) стандартів щодо компетенції та правил етики, що регулюють функціонування програм реституційного правосуддя [8].

Крім того, мають бути дотримані певні застереження; сторони повинні мати право на правову допомогу та, у разі необхідності, на тлумачення, роз'яснення. Підлітки повинні мати право на допомогу батьків [9].

Гарантії реалізації права на правову допомогу під час процедури примирення є однією зі складових частин гарантій доступу до юридичної допомоги. Як зазначає ПАРЕ у Резолюції № 2245 (2018) Асамблея, обов'язкова участь адвоката є однією 3 тих гарантій, які необхідні для того, щоб держави-члени користувалися потенційними перевагами, які можуть запропонувати системи відмови від судового розгляду, мінімізуючи загрози правам людини, зокрема праву на справедливий судовий розгляд [10].

У п. 8.1. зазначеної вище Резолюції Асамблея закликає всі держави-члени та держави, які мають статус спостерігача або інший статус у Раді Европи або Асамблеї, зробити обов'язковим залучення адвоката як умову дійсності угоди про визнання провини, у разі потреби за допомогою безоплатної юридичної допомоги для гарантування справедливого ставлення до відповідачів, зокрема вразливих, таких як молоді правопорушники, - як цього вимагає Стаття 6.3. с Конвенції [10].

Для порушника як сторони конфлікту держава повинна забезпечити ранній доступ до юридичної допомоги, а отже, до отримання консультації щодо позасудового вирішення кримінально-правового конфлікту. Відповідно до Керівництва Управління Організації Об'єднаних Націй з наркотиків і злочинності «Ранній доступ до юридичної допомоги в процесах кримінального правосуддя: керівництво для політиків і практиків» - означає доступ до юридичної допомоги 3 моменту підозри, арешту або затримання особи у зв'язку 3 кримінальним правопорушенням (залежно від того, яка подія настає раніше) і протягом всього періоду аж до першої появи перед суддею 3 метою визначення того, чи має обвинувачена особа бути затримано або звільнено в очікуванні суду.

Під юридичною допомогою при цьому «Принципи і керівні положення Організації Об'єднаних Націй, що стосуються доступу до юридичної допомоги в системах кримінального правосуддя» («UNPG») розуміють: юридичні консультації, допомогу i представлення осіб, затриманих, заарештованих або ув'язнених, підозрюваних або обвинувачених, або які притягуються до відповідальності у зв'язку 3 вчинення кримінальних правопорушень, а також жертв і свідків у процесі кримінального правосуддя, які надаються безкоштовно тим, хто не має достатніх засобів або коли того вимагають інтереси правосуддя [11].

Правова допомога покликана просувати концепції юридичної освіти, доступу до 
правової інформації та інших послуг, що надаються особам через альтернативні механізми вирішення спорів і процеси відновного правосуддя [11].

Відповідно до «Принципів і керівних положень Організації Об'єднаних Націй, що стосуються доступу до юридичної допомоги в системах кримінального правосуддя» («UNPG») держави повинні «гарантувати право на юридичну допомогу у своїх національних правових системах на найвищому рівні, включаючи, де це може бути застосовано, конституцію» (2013, Принцип 1).

Держави повинні розглядати надання правової допомоги своїм обов'язком. 3 цією метою вони мають розглянути, де це доречно, прийняття конкретного законодавства і нормативних актів і забезпечити наявність комплексної системи юридичної допомоги, яка була $б$ доступною, ефективною, стійкою і такою, що заслуговує довіри. Держави повинні виділяти необхідні людські та фінансові ресурси для системи юридичної допомоги [11].

Іншою гарантією реалізації права на компроміс у кримінальному судочинстві є інформування учасників про основні аспекти відновних процедур. Зміст положень Інструкції щодо кращого застосування чинної Рекомендації щодо медіації у кримінальних справах від 7 грудня 2007 р., прийнятої Европейською комісією 3 питань ефективного правосуддя, дозволяє виділити два рівні інформування: загальний та спеціальний кримінальнопроцесуальний.

Загальний рівень передбачає обов'язок держави вживати відповідні заходи для підвищення рівня обізнаності щодо переваг медіації серед широкої громадськості.

Такі заходи можуть передбачати: статті, інформаційні повідомлення в 3МІ, поширення інформації щодо медіації через буклети/брошури, Інтернет, плакати, телефонну лінію 3 питань медіації, інформаційні та консультаційні центри, цільові програми інформування, такі, як «тижні медіації», семінари та конференції, відкриті дні з медіації у судах та в організаціях, що надають послуги з медіації.
Держави, університети, інші наукові установи й зацікавлені особи повинні підтримувати та заохочувати проведення наукових досліджень у сфері медіації та відновного правосуддя.

Медіація та інші форми відновного правосуддя повинні бути включені в програми національної освіти у школах [12].

Спеціальний, кримінально-процесуальний рівень гарантування інформованості стосується конкретних сторін кримінально-правового конфлікту. Важливу роль у ньому відводить судам, прокуратурі та іншим органам кримінального правосуддя. Вони повинні бути здатними надати інформацію, організовувати інформаційні заходи з питань медіації та, де доречно, пропонувати потерпілим та/ чи правопорушникам взяти участь у медіації та/чи направити справу на медіацію. Країни-члени заохочуються налагоджувати та/чи вдосконалювати співпрацю між органами кримінального правосуддя та програмами медіації 3 метою здійснення більш ефективної роботи 3 потерпілими та правопорушниками [12].

Кодекс поведінки представників адвокатури також повинен містити зобов' язання або рекомендацію адвокатам вживати необхідних кроків для поширення відповідної інформації та, де доречно, пропонувати сторонам брати участь у медіації між потерпілим та правопорушником, а також захищати доцільність направлення справ на медіацію з боку компетентних органів [12].

У зв'язку з тим, що правоохоронні органи здійснюють втручання на ранніх етапах справи i, відтак, є першими, хто контактуе з потерпілими та правопорушниками, Інструкція щодо кращого застосування чинної Рекомендації щодо медіації у кримінальних справах звертає увагу на іхнє навчання, яке повинно передбачати досягнення розуміння відновного правосуддя.

Особлива увага повинна бути приділена питанню направлення справи на медіацію. Це може досягатись шляхом проведення навчання, яке включатиме інформацію про правопорушників та по- 


\section{Кримінальне право, кримінальний процес та криміналістика}

терпілих, а також шляхом поширення буклетів/брошур.

Як суд, так і прокуратура мають бути повністю поінформовані про процедуру медіації та бути свідомі щодо їі переваг та можливих ризиків. Це може досягатися через інформаційні заходи, а також базові й чинні навчальні програми.

Важливо заохочувати як інституційні, так і особисті контакти між медіаторами та суддями/прокурорами. Це може бути досягнуто, зокрема, шляхом проведення конференцій та семінарів.

Відновне правосуддя та медіація мають бути включені також до навчального плану як базових, так і чинних навчальних програм для адвокатів. Асоціації адвокатів повинні мати перелік організацій, що впроваджують програми медіації, та поширювати їх серед адвокатів.

Держава та асоціації адвокатів повинні вживати заходи для створення схем оплати праці адвокатів, які не відраджуватимуть їх від поради клієнтам щодо участі у медіації задля вирішення конфліктів [12].

3 огляду на закріплення у міжнародно-правових актах принципу добровільності альтернативних способів вирішення кримінально-правового конфлікту важливе значення має створення державою умов, які унеможливлюють примушування або схиляння сторін конфлікту 3 допомогою недобросовісних засобів до участі в процесах примирення або згоди 3 його результатами.

До таких умов необхідно віднести нормативне закріплення: 1) презумпції невинуватості у разі згоди порушника на застосування альтернативних способів вирішення кримінально-правового конфлікту; 2) недопустимості використання відомостей, повідомлених порушником під час процедури примирення, як доказів вини у подальшому судовому провадженні;3) доступності правосуддя та справедливого судового розгляду у випадку недосягнення компромісу.

Положення п. 9 Рекомендації № 6 R (87) 18 Комітету міністрів Ради Европи державам-членам «Стосовно спрощення кримінального правосуддя» 3 цього при- воду зазначає, що рішення органу, який здійснює переслідування обвинуваченого, про його умовне припинення не можна вважати еквівалентом засудження, доки обвинувачений не визнав своєї вини [13].

Відповідно до п. 7 принципів ООН реституційні процеси можуть застосовуватись лише за наявності достатніх доказів для пред'явлення обвинувачення правопорушника і вільно вираженої та добровільної згоди жертви і правопорушника [8].

Така ж умова передбачена п. 3 Рекомендації № 6 R (87) 18 Комітету міністрів Ради Европи державам-членам «Стосовно спрощення кримінального правосуддя» для застосування будь-яких інших альтернативних кримінальному переслідуванню способів вирішення кримінально-правового конфлікту, відповідно до якої рішення про відмову від переслідування може мати місце, якщо в органу, який здійснює таке переслідування, є адекватні докази вини [13].

Разом 3 тим слід погодитися 3 тим, що для застосування процедури примирення як альтернативної форми вирішення кримінально-правового конфлікту не завжди потрібне встановлення вини чи визнання iii обвинуваченим. Положення п.8 Принципів ООН визначає, що жертва і правопорушник повинні погоджуватися з основними обставинами справи як основи для їх участі у відновному процесі. Таким чином, конструкцію «визнання вини» замінює поняття «прийняття відповідальності за скоєне».

На практиці це означає, що суд, приймаючи кінцеве рішення у кримінальному провадженні, не зазначає у ньому, що обвинувачений «вину визнав» або «вину не визнав», а вказує на той факт, що він «згоден на примирення».

Із вимог п. 8 Принципів ООН про недопустимість використання у ході подальшого правового розгляду як доказів визнання порушником під час проведення компромісних процедур вини у вчинених діяннях, а також п. 14 принципів ООН про конфіденційний характер обговорень у рамках процедури примирення випли- 
ває обов'язок держави гарантувати право порушника відмовитися від дачі показань про обставини вчиненого кримінального правопорушення.

Крім того, кримінально-процесуальною гарантією реалізації права на компроміс повинно бути також закріплення положення про те, що факт недосягнення згоди під час процедури примирення не повинен використовуватися в рамках подальшого кримінального провадження. Відповідна вимога закріплена п. 16 Принципів ООН, а факт невиконання угоди чи іншого, ніж судове рішення, не повинен використовуватися як обгрунтування більш суворого вироку в ході подальшого кримінального провадження (п.17 Принципів ООН) [8].

Пунктом 16 Принципів ООН передбачено як гарантію реалізації права на компроміс у кримінальному судочинстві також доступ до правосуддя. Ця гарантія передбачає, що у тих випадках, коли домовленості між сторонами досягти не вдалось, справа повинна повернутись на розгляд у межах встановленого процесу кримінального правосуддя. Рішення щодо подальших дій повинно прийматись невідкладно.

Приймаючи рішення про участь у розв'язанні кримінально-правового конфлікту шляхом досягнення компромісу, особа повинна мати гарантії виконання умов досягнутих у такий спосіб домовленостей.

3 огляду на те, що за результатами досягнення компромісу сторони укладають угоду, їі предметом серед іншого $\epsilon$ конкретні зобов'язання, які повинна виконати та чи інша особа. Їх невиконання повинно тягнути за собою право іншої сторони звернутись до суду з вимогою зобов'язати недобросовісну сторону вчинити відповідні дії чи утриматись від них. Положення п.17 Принципів ООН з цього приводу зазначає, що у разі невиконання угоди, досягнутої в ході реституційного процесу, справу слід повернути на розгляд в реституційну програму або, якщо цього вимагає національне законодавство, на розгляд у рамках встановленого процесу кри- мінального правосуддя, i рішення щодо подальших дій має прийматися негайно. Схвалює закріплення цієї гарантії у національному законодавстві держав у своїй Резолюції № 2245 (2018) також і ПАРЕ, звертаючи увагу на заборону відмови від права на оскарження і можливість скасувати угоду за певних обставин [10].

\section{Висновки та перспективи подальших розвідок}

Таким чином, міжнародно-правові гарантії реалізації права на компроміс у кримінальному судочинстві - це положення міжнародно-правових актів, у яких закріплені правила обов'язкового та/або рекомендаційного характеру щодо діяльності органів державної влади та їх службових осіб, з метою забезпечення участі сторін у вирішенні кримінально-правового конфлікту шляхом застосування альтернативних (позасудових) примирювальних процедур.

Основними процесуальними гарантіями реалізації права на компроміс у кримінальному судочинстві, закріпленими на міжнародному рівні, є:

отримання юридичних консультацій сторонами щодо процедури примирення;

інформування учасників про основні аспекти відновних процедур;

- недопустимість примушування або схиляння сторін конфлікту 3 допомогою недобросовісних засобів до участі в процесах примирення або згоди 3 його результатами;

- забезпечення можливості повернення до розгляду кримінального провадження у межах встановленого процесу кримінального правосуддя у випадку недосягнення домовленості між сторонами у процесі процедур примирення;

- застосування кримінально-процесуальних санкцій до недобросовісної сторони у випадку виконання нею зобов'язань, взятих на себе за результатами примирення.

Дослідження зазначених міжнародно-правових гарантій реалізації особою права на компроміс у кримінальному су- 


\section{Кримінальне право, кримінальний процес та криміналістика}

дочинстві $є$ необхідною передумовою для подальших наукових розвідок 3 метою приведення у відповідність до них положень чинного кримінального процесуального законодавства України.

\section{Мітература \\ 1. Рішення ЕСП $\Lambda$ у справі} «Natsvlishvili та Togonidze проти Грузії» (Заява № 9043/05) від 29 квітня 2014 року. [Електронний ресурс]. - Режим доступу: http://hudoc.echr.coe.int/app/conversion/ $\mathrm{docx} / \mathrm{pdf}$ ? library $=\mathrm{ECHR} \& \mathrm{id}=001 \% 20$ 153730 \& fil en a m e = C A E \% 20 O F \% $20 \mathrm{NATS}$ V L I S H V I L I \% 20 A N D \% 20 T O GO N I D E \% 20 v. \% 20 GEORGIA\%20-\%20\%5 B Ukrainian $\% 20$ Translation $\% 5 \mathrm{D} \% 2 \mathrm{By} \% 20$ the $\% 20 \mathrm{COE} \% 20$ Human\%20 Rights\%20 Trust\%20 Fund. pdf\&logEvent $=$ False

2. Трекке А. С. Кримінальне провадження на підставі угоди про визнання винуватості : Автореф. дис. ... канд. юрид. наук : 12.00.09 / А.С. Трекке. - Ірпінь, 2018. - 23 с.

3. Саєнко Г.Ю. Провадження на підставі угод у кримінальному процесі України: Автореф. дис. ... канд. юрид. наук: 12.00.09 / Г.Ю. Саєнко. - К., 2017. - 20 с.

4. Кокорев А.Д. Общественные и личные интересы в уголовном судопроизводстве / под ред. А.Д. Кокорева. - Воронеж : Изд-во Воронеж. ун-та, 1984. - 159 с.

5. Горский Г.Ф. Проблемы доказательств в советском уголовном процессе / Г.Ф. Горский, А.Д. Кокорев,П.С. Элькинд. - Воронеж, Изд-во Воронеж. ун-та, 1978. - 303 с.

6. Стройкова А.С. Гарантии прав обвиняемого на предварительном следствии: Дисс. ... канд. юрид. наук: 12.00.09 / А.С. Стройкова. - Ростов-на-Дону, 2005. $-141 \mathrm{c}$.

7. Курс советского уголовного процесса. Общая часть / Алексеев В.Б., Алексеева Л.Б., Божьев В.П., Бойков А.Д., и др.; Под ред.: Бойкова А.Д., Карпеца И.И. - М.: Юрид. лит., 1989. - 640 с.

8. Основні принципи застосування програм реституційного правосуддя в питаннях кримінального правосуддя. Резо- люція 2002/12 Економічної і Соціальної Ради від 24 липня 2002 р. [Електронний ресурс]. - Режим доступу: https://www. unodc.org/documents/justice-and-prisonreform/R_ebook.pdf

9. Реккомендація № R (99) 19 Комітету міністрів Ради Европи державам - членам Ради, які зацікавлені в організації медіації у кримінальних справах, прийнята Комітетом міністрів на 679-й зустрічі представників Комітету від 15 вересня 1999 р. [Електронний ресурс]. - Режим доступу: https://zakon.rada.gov.ua/laws/ show/994_828\#Text

10. Укладання угод у кримінальному провадженні: необхідність мінімальних стандартів для систем відмови від судового розгляду. Резолюція ПАРЕ №2245 (2018) від 12 жовтня 2018 р. [Електронний ресурс]. - Режим доступу: https:// www.echr.com.ua/document/rezolyuciyaparye-2245-2018/

11. Принципы и руководящие положения Организации Объединенных Наций, касающиеся доступа к юридической помощи в системах уголовного правосудия: резолюция, принятая Генеральной Ассамблеей 28 марта 2013, A/RES/67/187. [Електронний ресурс]. - Режим доступу: https:// ips.ligazakon.net/document/MU13168

12. Інструкція щодо кращого застосування чинної Рекомендації щодо медіації у кримінальних справах. Матеріали Европейської комісії 3 питань ефективного правосуддя від 7 грудня 2007 р. // Відновне правосуддя в Україні. - 2008. - № 3 (11). - C. 32-36.

13. Стосовно спрощення кримінального правосуддя. Рекомендація № $6 \mathrm{R}$ (87) 18 Комітету міністрів Ради Европи державам-членам від 17 вересня 1987 р. [Електронний ресурс]. - Режим доступу: https:// zakon.rada.gov.ua/laws/show/994_339\#Text

\section{INTERNATIONAL GUARANTEES OF THE RIGHT TO COMPROMISE IN CRIMINAL JUDICIARY}

The author of the article analyzes the main guarantees of the right to compromise, enshrined in international legal instruments. 


\section{АНОТАЦІЯ}

Автор статті аналізуе основні гарантӥ реалізащії особою права на компроміс, закріплені у міжнародно-правових актах. На основі дослідження наукових праць розкривається поняття кримінальних процесуальних гарантій та їх характеристика. За результатами дослідження робиться висновок про те, що міжнародноправові гарантї реалізащї права на компроміс у кримінальному судочинстві - ие положення міжнародно-правових актів, у яких закріплені правила обов'язкового та/або рекомендаційного характеру щодо діяльності органів державної влади та їх службових осіб, з метою забезпечення участі сторін у вирішенні кримінально-правового конфлікту шляхом застосування альтернативних (позасудових) примирювальних прочедур. Основна увага приділяеться таким гарантіям, як отримання юридичних консультачій сторонами щодо прочедури примирення; інформування учасників про основні аспекти відновних процедур; недопустимість примушування або схиляння сторін конблікту з допомогою недобросовісних засобів до участі в прочесах примирення або згоди з його результатами; забезпечення можливості повернення до розгляду кримінального провадження у межах встановленого процесу кримінального правосуддя у випадку недосягнення домовленості між сторонами у процесі процедур примирення; застосування кримінально-прощесуальних санкцій до недобросовісної сторони у випадку виконання нею зобов'язань, взятих на себе за результатами примирення. У статті звертається увага на роль правоохоронних органів у забезпеченні права на компроміс. Це пов'язано з тим, шо саме вони здійснюють втручання на ранніх етапах справи $i$, відтак, є першими, хто контактує з потерпілими та правопорушниками. Автор зазначає, що увага правоохоронних органів повинна бути приділена питанню направлення справи на процедуру примирення. Як суд, так і прокуратура мають бути повністю поінформовані про процедури примирення та бути свідомі щодо їх переваг та можливих ризиків. Це може досягатися через інформаиійні заходи, а також базові й чинні навчальні програми.

Ключові слова: міжнародний, гарантї, компроміс, примирення, правова допомога, інформування, конфбікт.
On the basis of research of scientific works the concept of criminal procedural guarantees and their characteristic is revealed. According to the results of the study, it is concluded that international legal guarantees for the exercise of the right to compromise in criminal proceedings are provisions of international legal acts, which enshrine mandatory and / or recommendatory rules on the activities of public authorities and their officials, in order to ensure the participation of the parties in resolving the criminal conflict by applying alternative (extrajudicial) conciliation procedures. The focus is on guarantees such as legal advice to the parties on the conciliation procedure; informing participants about the main aspects of recovery procedures; inadmissibility of forcing or inclining the parties to the conflict by unfair means to participate in the reconciliation process or agreeing with its results; ensuring the possibility of returning to criminal proceedings within the established criminal justice process in case of failure to reach an agreement between the parties in the process of conciliation procedures; application of criminal procedural sanctions to the unscrupulous party in case of fulfillment of the obligations undertaken as a result of conciliation. The article draws attention to the role of law enforcement agencies in ensuring the right to compromise. It is determined by their contacts with victims and offenders from the initial stages of criminal proceedings. The author notes that the attention of law enforcement agencies should be paid to the issue of referring the case to the conciliation procedure. Both the court and the prosecutor's office should be fully informed about conciliation procedures and be aware of their benefits and possible risks.

Key words: international, guarantees, compromise, reconciliation, legal assistance, information, conflict. 